\title{
Factors Influencing Customer Satisfaction or Dissatisfaction in the Restaurant Business Using AnswerTree Methodology
}

\author{
Jinsoo Hwang, Ph.D. Student \\ Hospitality Management and Dietetics \\ Kansas State University \\ 2050 Kerr Drive Apt. Q21 \\ Manhattan, Kansas 66502, USA \\ Cell: (415) 630-3198 \\ Fax: (785) 532-5522 \\ jinsoo@ksu.edu \\ Jinlin Zhao, Ph.D., Associate Professor \\ School of Hospitality \& Tourism Management \\ Florida International University \\ 3000 NE 151 Street, HM 336 \\ North Miami, FL 33181 \\ Cell: (305) 919-4540 \\ Fax: (305) 919-4555 \\ zhaoj@fiu.edu
}

Published in: Journal of Quality Assurance in Hospitality \& Tourism, Volume 11, Issue 2 April 2010, pages $93-110$. 


\title{
Factors Influencing Customer Satisfaction or Dissatisfaction in the Restaurant Business Using AnswerTree Methodology
}

\begin{abstract}
In the restaurant business, customer satisfaction can be linked directly to restaurant sales; thus, it is important to identify which perceived quality factors more strongly affect customer satisfaction or dissatisfaction. The purpose of this study was to find differences between satisfied and dissatisfied customers. The major analytical method used was AnswerTree. As AnswerTree method allows the researcher to more effectively target exact groups of people, it is a suitable analysis method to find differences between satisfied and dissatisfied customer groups. Study results indicated three perceived quality factors (good value, tasty food, and restaurant cleanness) most affected satisfied customers. On the other hand, three perceived quality factors (good value, tasty food, and employees' knowledge of menu) most affected dissatisfied customers. Study results provide some meaningful information for restaurateurs in making a marketing strategy.
\end{abstract}

KEYWORDS: Customer satisfaction, perceived quality, AnswerTree, CHAID 


\section{INTRODUCTION}

Restaurants are one of the many businesses that affect economic growth in the U.S. According to the National Restaurant Association (2009), with 945,000 restaurant locations nationally, the restaurant industry's direct sales are $\$ 566$ billion a year, or more than $\$ 1.55$ billion a day. Including the impact restaurants have on sales in related industries, the industry's overall impact on the U.S. economy is $\$ 1.5$ trillion a year (about $4 \%$ of the U.S. gross domestic product). To find the ideal marketing strategy, many restaurateurs have spent considerable time and effort trying in order to sustain their status in a competitive restaurant market. Generally, they consider that customer satisfaction is a crucial factor in their competitive fields. As customer satisfaction could greatly affect predicting customer post-purchase behavior (Tam, 2000), the concept of customer satisfaction has become an important topic in many restaurants and in academic research. Unfortunately, although there is no assurance that the customer will make a return visit due to the intangible nature of services (Dube, Renaghan, and Miller, 1994), customer satisfaction could become one of the most important factors for determining whether customers have the intent of returning or not (Oh, 2000; Yüksel and Yüksel, 2002). Furthermore, customer satisfaction can be linked directly to business sales (Baker and Crompton, 2000; Chow et al., 2007; Heskett, Sasser, and Schlesinger, 1997; Mohsin, 2005; Zeithaml and Bitner, 2000). Thus, if restaurant marketers know which perceived quality factors have the greatest impact on restaurant customer satisfaction or dissatisfaction, they could have a good way to find the chief element of success or failure in a restaurant's management.

The aim of this study was to find differences between satisfied and dissatisfied customers based on perceived quality. This research revealed which perceived quality factors more strongly affect satisfied and dissatisfied customers in the restaurant business. Study results can help 
restaurateurs to develop marketing strategies that can be successfully used by full-service restaurant operators. Before we discuss the results of this study, we will review the literature about customer satisfaction and perceived quality.

\section{LITERATURE REVIEW}

As customer satisfaction is the most important factors affecting service management, it is important to marketers and scholars (Rust and Oliver, 1994). In fact, many researchers have applied customer satisfaction to the service industry (e.g. Almanza, Jaffe, and Lin, 1994; Andaleeb and Conway, 2006; Barsky and Labagh, 1992; Gabbie and O'Neil, 1996; James, 1995; Johns and Tyas, 1996; Oh, 1999, 2000; Oliver, 1980, 1981). Furthermore, due to the influence of customer satisfaction on repeat purchases and word-of-mouth recommendations, customer satisfaction is deemed to be critical for all businesses (Berkman and Gilson, 1986; Yüksel and Yüksel, 2002). Many scholars have defined customer satisfaction differently. According to Dube et al., (1994), customer satisfaction is "an indicator of whether customers will return to a restaurant" (p. 39), or "customer satisfaction is the leading criterion for determining the quality actually delivered to customers through the product/service and by the accompanying servicing" (Vavra, 1997, p. 8). Although many scholars suggest various definitions of customer satisfaction, the definition proposed by Oliver (1980) has been mostly widely accepted (Pizam and Ellis, 1999). Many researchers have tried to verify the validity of this theory (e.g. Oliver and DeSarbo, 1988; Tse and Wilton, 1988). To summarize Oliver's theory, customers are used to buying a product or service with expectations based on previous experience. In other words, before they buy the product or service, customers already have a certain level of expectation. And then, once they buy the product or service, they compare the new one with the previous product or service. 
At this time, confirmation or disconfirmation occurs. If the customer can accept the outcome compared with his or her expectations, confirmation will occur. On the other hand, if the customer cannot accept the outcome, disconfirmation will occur. There are two kinds of disconfirmation, which are positive disconfirmation and negative disconfirmation. When the outcome of the product or service is less than the customer expects, negative disconfirmation will occur. On the other hand, when the customer feels better about the outcome than the expectation, positive disconfirmation will occur. In summary, customer satisfaction occurs by confirmation or positive disconfirmation of consumer expectations, and dissatisfaction occurs by negative disconfirmation of consumer expectations.

According to Tam (2000), there is a close link between service quality and customer satisfaction. As service quality is deemed a significant factor in increasing customer satisfaction and loyalty, the significance of service quality has been studied by academics and practitioners (e.g. Dukart, 1998; Leal and Pereira, 2003; Umbrell, 2003; Parasuraman, Zeithaml, and Berry, 1985, 1988, 1994). In addition, service quality has been well recognized for playing a crucial role in improving organizational profits because it is directly related to customer satisfaction, and customer loyalty (Baker and Crompton 2000; Leal and Pereira, 2003; Zeithaml and Bitner, 2000). In fact, numerous researchers have studied the measurement of service quality. The most well known instrument for measuring service quality is SERVQUAL, which was introduced by Parasuraman et al. (1988). Since its introduction, SERVQUAL has been widely applied in many industries for measuring customer perceptions of service quality (Parasuraman, Berry, and Zeithaml, 1991). Parasuraman et al. (1988) suggested that customer perceptions of service quality can be measured by the gap between customer expectation and perceptions of performance levels. SERVQUAL consists of five distinct dimensions with 29 specific operating 
statements. The dimensions are: assurance (knowledge and courtesy of employees and their ability to inspire trust and confidence), empathy (caring, individualized attention the firm provides its customers), reliability (ability to perform the promised service dependably and accurately), responsiveness (willingness to help customers and provide prompt service), and tangibles (physical facilities, equipment, and appearance of personnel). Because it is a simple and inexpensive instrument, SERVQUAL has been applied in various fields and provided meaningful information (Heung, Wong, and Qu, 2000). However, SERVQUAL dimensions should be necessary to remove or revise in particular different service areas (Carman, 1990). Subsequently, Stevens, Knutson, and Patton (1995) designed a perceived quality scale, DINESERV, by modifying SERVQUAL in order to apply it to the restaurant business. Although DINESERV included some items to measure the atmospherics quality, they missed the factor of food quality, which is one of the most important factors when assessing overall customer experience in the restaurant (Kivela, Inbakaran, and Reece, 1999; Raajpoot, 2002). Carrying the previous study a step further, Mohsin (2005) studied perceived quality that included the factor of food quality based on SERVQUAL and DINESERV. In this study, we categorized four perceived quality factors influencing customer satisfaction: service quality, food quality, atmospherics, and other factors including price, parking space, and location.

\section{RESEARCH METHODOLOGY}

\section{Data Collection and Questionnaire}

The data used for this study were collected in Miami. Surveys were conducted from May 1 to May 31, 2007. Because 15 minutes is enough time to complete all questionnaires, surveys commenced with a question saying whether respondents have 15 minutes or not. Furthermore, 
survey did not allow to young people under the age of 18 to participate because of their lack of knowledge about the subject. Finally we selected respondents who had visited a full-service restaurant within the last one month. The selected full-service restaurants provided full table services and the average guest check was at least $\$ 25$ per person. Of the 414 questionnaires collected, 24 were incomplete and were eliminated. As a result, a total of 390 questionnaires were used in the data analysis.

The dependent variable was customer response in relation to level of satisfaction after a dining experience. The dependent variable was composed of three groups: "agree," "neutral," and "disagree." Among the respondents $(n=390), 84.36 \%(n=329)$ indicated that the experience of visiting the restaurant was good (agree), $12.05 \%(n=47)$ of the respondents thought that the restaurant was bad (disagree), and 3.59\% $(n=14)$ of them indicated "neutral." The independent variables were perceived quality factors that influence customer satisfaction. In this study, 18 items were mainly cited from the Mohsin (2005) study. Some new items were added from Stevens et al. (1995). A total of 18 perceived quality factors were classified into four categories: service-related attributes, food-related attributes, atmosphere-related attributes and other attributes. Service-related attributes consisted of six measurement items: "The service was prompt," "Sauces, utensils, napkins, etc., were readily available on the table," "The order was correct and complete," "Employees spoke clearly," "Employees were friendly and courteous," and "Service employees had adequate product knowledge to make good suggestions for food." Food-related attributes included five measurement items: "The food quality was excellent," "The food temperature was good," "The food was tasty," "The drink was excellent," and "The menu had a good variety of items." Atmosphere-related attributes included four measurement items: "The employee uniform was appropriate," "Restaurant had a good ambience," "Restaurant was 
clean," and "The menu was easy to read." Other attributes included "Restaurant had adequate parking spaces," "Location of the restaurant was convenient," and "I received a good value for my money." The questionnaire was made of a seven-point Likert scale, and each scale item was rated by asking respondents to indicate their level of agreement ranging from strongly disagree (1) to strongly agree (7). To apply CHAID (Chi-square Automatic Interaction Detection) analysis, researchers converted the seven-point scale into categorical variables (agree, neutral, disagree). Even though respondents answered five or six on the seven-point scale, it could be agreed that the information sufficiently ensured their positive response. As a result, in this study, five, six, and seven points were converted into a positive response (agree). In contrast, one, two, and three points converted into a negative response (disagree). Finally, four in the seven-point scale was converted into a neutral response. The summary of data description is presented in Table 1.

\section{Insert Table 1}

\section{Data Analysis Method}

The major analytical measurement was AnswerTree methodology. The purpose of this study was to find important perceived quality factors that satisfied and dissatisfied customers consider when dining at a full-service restaurant. As AnswerTree method allows the researcher to more effectively target exact groups of people (2009), it is a suitable analysis method to find differences between satisfied and dissatisfied customer groups. The purpose of the AnswerTree method is to predict or sort the targeting variable (dependent variable) by dividing observation (independent variable). As AnswerTree uses fixed rules to link between predictors (independent 
variable) when determining splits, the researchers can easily understand the targeting segmentations which will respond to the purpose of study (SPSS, 1998). Therefore, AnswerTree has been applied in many fields. For instance, according to SPSS (2009), AnswerTree can analyze data to:

- Know potential customers

- Find which customer groups buy specific products

- Identify which customers will most likely defect

AnswerTree method automatically provides the best tree structure on the basis of variations of likelihood-ratio chi-square values when each independent variable is used for constructing the tree (SPSS, 1998). The dependent variable can be sorted by the level of whichever independent variable that has the strongest relationship with the dependent variable. That is, the most important independent variable with a dependent variable can be the first node. This process is done when one of three criteria is met from Berson, Smith, and Thearling (2000):

1. The segment contains only one record. (There is no other question that you can ask to further refine a segment of just one.)

2. All the records in the segment have identical characteristics. (There is no reason to continue asking further questions because all the remaining records are the same.)

3. The improvement is not substantial enough to warrant asking the question (p. 162). AnswerTree has three decision-making options, which are CHAID (Chi Square Automatic Interaction Detector), CART (Classification and Regression Trees), and QUEST (Quick, Unbiased, Efficient, Statistical Tree) to find the targeting group using the tree structure. Among the three decision-making options, since the categorical variable was applied for analyzing data in this study, the CHAID method, which is fit to the categorical variable, was 
used. Kass (1980) firstly developed the original CHAID algorithm for categorical dependent variables. It was further extended to ordinal dependent variables by Magidson (1994). The CHAID analysis is applicable to situations where all variables, independent and dependent variable, are categorical. The dependent variable can have more than two categories. Since CHAID algorithm is one of the most effective data mining methods, it has widely been applied in the consumer research area (Chen, 2003; Haughton and Oulabi, 1997; Levin and Zahavi, 2001). All variables used in this study are categorical measurements with two or more categorical levels. The stopping rules for AnswerTree analyses are a maximum tree depth of 3 , minimum number of case of 25 for a given node.

\section{RESULT}

\section{Demographic Profile of Respondents}

Descriptive statistics were used to present the characteristics of the respondents. A total of 390 respondents were involved in this survey. Among the respondents $(n=390), 203(52.1 \%)$ were male, and 187 (47.9\%) were female. The majority of participants were White/Caucasian $(132,33.8 \%)$, and 92 respondents $(23.6 \%)$ were Hispanic. Finally, regarding their annual household income, the highest percentage of respondents earned between $\$ 40,000$ (33.1\%). Table 2 presents details on the gender, age, marital status, ethnicity and income.

Insert Table 2

\section{AnswerTree Analysis Results}


Figure 1 shows a general model of satisfied and dissatisfied groups. Before conducting analysis, the researchers expected three groups (disagree, soso, agree) would be divided by perceived quality variables. However, because "soso" group has small sample size $(n=8)$, two groups (agree and disagree groups) were classified by the perceived quality variables. In this study, 12 nodes were used to explain perceived quality factors affecting satisfied and dissatisfied groups.

\section{Insert Figure 1}

\section{AnswerTree Analysis Results: Satisfied Group}

Considering the results of the satisfied group (agree) in Figure 2, the first split was "I received a good value for my money (agree)" $\left(\chi^{2}=384.4955\right.$, d.f. $\left.=4 ; p=.000\right)$. In Node $3,98.75 \%$ $(n=317)$ of respondents showed that the majority felt the "level of satisfaction" was good whereas $0.31 \%(n=1)$ had negative feelings regarding the "level of satisfaction." Node 3 was divided into two groups: Node 7 and Node 8 . The second pruning tree was based on the variable of "The food was tasty (agree)" $\left(\chi^{2}=30.5869\right.$, d.f. $\left.=2 ; p=.000\right)$. In Node $8,99.35 \%(n=306)$ of respondents agreed that "level of satisfaction" was good and the Node 8 was pruned into two groups which were Node11 and Node 12. The last split was "Restaurant was clean (agree)" $\left(\chi^{2}=2.3481\right.$, d.f. $\left.=1 ; p=.1254\right)$. In Node $12,99.63 \%(n=266)$ of respondents agreed that "level of satisfaction" was good. That is, people who felt that the restaurant was clean agreed that the "level of satisfaction" was good. However, in this case, the $p$-value is less than 0.05 , so we can not say that clean was an important factor in explaining the level of satisfaction. In summary of 
the satisfied group, there were two descriptors. They were "I received a good value for my money" and "The food was tasty."

\section{Insert Figure 2}

\section{AnswerTree Analysis Results: Dissatisfied Group}

In the case of the results of the dissatisfied group (disagree) in Figure 3, the first split was "I received a good value for my money (disagree)" $\left(\chi^{2}=384.4955\right.$, d.f. $\left.=4 ; p=.000\right) .84 .36 \%$ $(n=329)$ of respondents showed that they felt the "level of satisfaction" was good whereas $12.05 \%(n=47)$ had negative feelings regarding the "level of satisfaction." Node 1 was then divided into three groups: Node 4, Node 5, and Node 6 . The second pruning tree was based on the variable of "The food was tasty (disagree)" $\left(\chi^{2}=64.5035\right.$, d.f. $\left.=4 ; p=.000\right)$. In Node $4,97.73 \%$ $(n=43)$ of respondents disagreed with "level of satisfaction" was good, and Node 8 was pruned into two groups, which were Node 9 and Node 10. The third split was "Service employees had

adequate product knowledge to make good suggestions for food (disagree, neutral)" $\left(\chi^{2}=21.4884\right.$, d.f. $=1 ; p=.000)$. In Node $9,100.00 \%(n=42)$ of respondents thought that "level of satisfaction" was not good. That is, people who thought that "level of employees' knowledge" was not good agreed that "level of satisfaction" was bad. In summary of the dissatisfied group (disagree)," there were three descriptors which were "I received a good value for my money", "The food was tasty", and "Service employees had adequate product knowledge to make good suggestions for food."

Insert Figure 3 


\section{AnswerTree Analysis Results: Bar Graph}

Figure 4 is a bar graph that summarizes the statistics as a graph. The bar graph allows readers to figure out which node most represents the dependent variable showing variation of each dependent variable. In this study, two groups in the dependent variables were classified by a maximum tree depth of 3 , minimum number of case of 25 for a given node. The bar graph of AnswerTree showed that certain nodes most represent satisfied and dissatisfied groups, respectively (Node 12: satisfied group, Node 9: dissatisfied group).

\section{Insert Figure 4}

\section{AnswerTree Analysis Results: Gain Chart Results}

Table 3 presents a gain chart of the satisfied group. A gain chart is a table summarizing the whole model with a description. As stated in the bar graph, certain nodes most represent dependent variables on the graph. In the gain chart, we can know well what percentage each node represents for the dependent variable. In the case of the satisfied group, the root node was $84.36 \%(n=77)$. Node 12 was computed by taking 99.62\% (Gain: \% computed from Node: $\mathrm{N}$ divided by Resp: $\mathrm{N}$ ) and then dividing it by $84.36 \%$ (root node). The results were $118.09 \%$, the index score for Node 12 . Thus, nodes that had a gain index of over $100 \%$ were considered to be groups showing a higher percentage of respondents with a higher satisfaction. In other words, two variables ("I received a good value for my money," "The food was tasty") were important factors in explaining the satisfied group. 


\section{Insert Table 3}

Table 4 presents a gain chart of the dissatisfied group. In the case of the dissatisfied group, the root node was $12.05 \%(n=77)$. Node 9 was computed by taking $100.00 \%$ (Gain: $\%$ computed from Node: $\mathrm{N}$ divided by Resp: $\mathrm{N}$ ) and then dividing it by $12.05 \%$ (root node). The results are $829.78 \%$, the index score for Node 9. That is, Node 9 ("I received a good value for my money": disagree, "The food was tasty": disagree, "Service employees had adequate product knowledge to make good suggestions for food": disagree) represents a root node about 8.29 times. Thus, in the case of the dissatisfied group, three variables were important factors.

\section{Insert Table 4}

\section{AnswerTree Analysis Results: Risk Chart}

Table 5 shows a risk chart indicating the preciseness of classification. It is similar to the percentage of classified respondents in the discriminant analysis. The risk estimate predicted the risk incurred due to misclassification of the respondents in AnswerTree program. The less the estimate, the more precisely classified was the model. Table 4 indicates a risk chart of "level of satisfaction." According to the results of the assessment of revisit intention, the risk estimate was 0.0384615. This means that the preciseness of classifying respondents on AnswerTree analysis was $99.9615385 \%$. That is, about $99.96 \%$ of the respondents were classified accurately on split nodes.

Insert Table 5 


\section{DISCUSSION AND IMPLICATIONS}

In today's competitive business environment, customer satisfaction is the key to a restaurant's success (Chow et al., 2007; Heskett et al., 1997; Palmer, 2001). Especially because of their significance in influencing post-purchase behavior (Tam, 2000), customer satisfaction has long attracted the interests of many researchers. This study revealed that there were different perceived quality factors in explaining customer satisfaction and dissatisfaction when using the full-service restaurant. Among the respondents $(n=390), 84.36 \%(n=329)$ indicated that the experience of visiting the restaurant was good; on the other hand $12.05 \%(n=47)$ of the respondents thought that the restaurant was bad and 3.59\% $(n=14)$ of them thought "neutral." Study results revealed that there were three descriptors which were ranked by the order of "I received a good value for my money," "The food was tasty," and "Service employees had adequate product knowledge to make good suggestions for food" to divide into satisfied and dissatisfied groups. The first descriptor was "I received a good value for my money." This result could support previous studies (Jayanti and Gosh, 1996; Parasuranman et al., 1984; Zeithaml, 1988). They emphasized that high perception of perceived value leads to greater satisfaction, and in turn, affects repurchase intentions. That is, high perception of perceived value triggers a satisfying feeling. The second descriptor was "The food was tasty," which was highly correlated with satisfaction in this study. In other words, the restaurateur should pay more attention to taste in food to enhance customer satisfaction, which finding is consistent with previous studies (Dube et al., 1994; Witkowski, Ma, and Zheng, 2003). Finally the results also suggested that the level of employees' knowledge could be a critical factor that creates high satisfaction from restaurant customers. Dissatisfied customers felt more dissatisfaction due to lack of employees' knowledge. 
According to Chow et al. (2007), service training is the key factor in increasing the ability of employees to deliver good service and to satisfy customers' needs. Generally, because there is no well-organized training system in the restaurant business except in well-known restaurants, some employees have an imperfect knowledge of service, and therefore do not satisfy the customers. From the managerial standpoint, although it costs a great deal to train employees, the restaurateur should consider systematic training and also invest effort and time for the long-term view.

As "a high level of customer satisfaction leads to an increase in repeat patronage among current customers" (Yüksel and Yüksel, 2002, p. 52), knowing which perceived quality factors impact on customer satisfaction is important. In this research, AnswerTree indicated results of significant and positive on the level of satisfaction based on perceived quality. Although it is hard to say only perceived quality is enough to explain all customer satisfaction, it is necessary in the competitive restaurant business. If restaurateurs are careless when measuring or focusing on customer satisfaction, they can bring on business failures (Dube et al., 1994). That is, ignoring customer satisfaction may cause lower customer satisfaction and reduced repeat business.

The following limitations for this research should be borne in mind. The data was collected in the Miami area only. Thus, the findings might not be generalized to other areas. Another limitation is that the results of this study cannot be applied in all services because the focus is on restaurant services only. In addition, because its focus is on full-service restaurants only, the findings must be applied to other restaurants, such as fast food restaurants or family restaurants, with due caution.

\section{REFERENCES}

Almanza, B. A., Jaffe, W., \& Lin, L. C. (1994). Use of the service attribute matrix to measure consumer satisfaction. Hospitality Research Journal, 17(2), 63-75. 
Andaleeb, S. S., \& Conway, C. (2006). Customer satisfaction in the restaurant industry: An examination of the transaction-specific model. Journal of Services Marketing, 20(1), 311.

Baker, D., \& Crompton, J. (2000). Quality, satisfaction, and behavioral intentions. Annals of Tourism Research, 27(3), 785-804.

Barsky, J. D., \& Labagh, R. (1992). A strategy for customer satisfaction. Cornell Hotel and Restaurant Administration Quarterly, 33(5), 32-40.

Berkman, H. W., \& Gilson, C. (1986). Consumer behavior: Concepts and strategies, $3^{\text {rd }}$ ed. Boston: Kent.

Berson, A., Smith, S., \& Thearling, K. (2000). Building data mining applications for CRM. McGraw-Hill.:USA.

Carman, J. M. (1990). Consumer perceptions of service quality: An assessment of the SERVQUAL dimensions. Journal of Retailing, 66(2), 33-55.

Chen, J. S. (2003). Market segmentation by tourists' sentiments. Annals of Tourism Research, 30(1), 178-193.

Chow, I. H.-s., Lau, V. P., Lo, T. W.-c., Sha, Z., \& Yun, H. (2007). Service quality in restaurant operations in China: Decision- and experiential-oriented perspectives. International Journal of Hospitality Management, 26(3), 698-710.

Dube, L., Renaghan, L. M., \& Miller, J. M. (1994). Measuring customer satisfaction for strategic management. Cornell Hotel and Restaurant Administration Quarterly, 35(1), 39-47.

Dukart, J. R. (1998). Quality: Do you measure up?. Utility Business, 1(4), 32-38.

Gabbie, O., \& O'Neil, M. (1996). SERVQUAL and the Northern Ireland hotel sector: A comparative analysis. Managing Service Quality, 6(6), 25-32.

Haughton, D., \& Oulabi, S. (1997). Direct marketing modeling with CART and CHAID. Journal of Interactive Marketing, 11(4), 42-53.

Heskett, J. R., Sasser, W. E., \& Schlesinger, L. (1997). The service profit chain: How leading companies link profit and growth to loyalty, satisfaction, and value. Free Press, New York.

Heung, V. C. S., Wong, M. Y., \& Qu, H. (2000). Airport restaurant service quality in Hong Kong: An application of SERVQUAL. Cornell Hotel and Restaurant Administration Quarterly, 41(3), 86-97.

James, L. W. (1995). Service encounter satisfaction: Conceptualized. Journal of Services Marketing, 9(1), 5-14.

Jayanti, R. K., \& Gosh, A. K. (1996). Service value determination: An integrative perspective. Journal of Hospitality \& Leisure Marketing, 3(4), 5-25.

Johns, N., \& Tyas, P. (1996). Investigation of the perceived components of the meal experience, using perceptual gap methodology. Progress in Tourism and Hospitality Research, 3(1), 15-26.

Kass, G. (1980). An exploratory technique for investigating large quantities of categorical data. Applied Statistics, 29(2), 119-127.

Kivela, J., Inbakaran, R., \& Reece, J. (1999). Consumer research in the restaurant environment, Part 1: A conceptual model of dining satisfaction and return patronage. International Journal of Contemporary Hospitality Management, 11(5), 205-222.

Leal, R. P., \& Pereira, Z. L. (2003). Service recovery at a financial institution. International Journal of Quality and Reliability Management, 20(6), 646-663. 
Levin, N., \& Zahavi, J. (2001). Predictive modeling using segmentation. Journal of Interactive Marketing, 15(2), 2-22.

Magidson, J. (1994). The CHAID approach to segmentation modeling: Chi-Square automatic interaction detection. Advanced Method of Marketing Research, Blackwell, Cambridge MA.

Mohsin, A. (2005). Service quality perceptions: An assessment of restaurant and café visitors in Hamilton, New Zealand. The Business Review, 3(2), 51-57.

National Restaurant Association (2009). Restaurant Industry Overview. Retrieved from http://www.restaurant.org/research/ind_glance.cfm

Oh, H. (1999). Service quality customer satisfaction and customer value: A holistic perspective. Hospitality Management, 18(1), 67-82.

Oh, H. (2000). Diners' perceptions of quality, value, and satisfaction: A practical viewpoint. Cornell Hotel and Restaurant Administration Quarterly, 41(3), 58-66.

Oliver, R. L. (1980). A cognitive model of the antecedents and consequences of satisfaction decistions. Journal of Marketing Research, 17(11), 460-469.

Oliver, R. L. (1981). Measurement and evaluation of satisfaction processes in retail settings. Journal of Retailing, 5(7), 25-48.

Oliver, R. L., \& DeSarbo, W.S. (1988). Response determinants in satisfaction judgments. Journal of Consumer Research, 14(3), 495-507.

Palmer, A. (2001). Principles of service marketing. McGraw-Hill, New York.

Parasuraman, A., Berry, L. L., \& Zeithaml, V. A. (1991). Understanding customer expectations of service. Sloan Management Review, 32(3), 420-450.

Parasuraman, A., Zeithaml, V. A., \& Berry, L. L. (1985). A conceptual model of service quality and its implications for future research. Journal of Marketing, 49(4), 41-50.

Parasuraman, A., Zeithaml, V. A., \& Berry, L. L. (1988). SERVQUAL: A multiple-item scale for measuring consumer perceptions of service quality. Journal of Retailing, 64(1), 1240.

Parasuraman, A., Zeithaml, V. A., \& Berry, L. L. (1994). Reassessment of expectations as a comparison standard in measuring service quality: Implications for further research. Journal of Marketing, 58(1), 111-124.

Pizam, A., \& Ellis, T. (1999). Customer satisfaction and its measurement in hospitality enterprises. International Journal of Contemporary Hospitality Management, 11(7), 326-347.

Raajpoot, N. A. (2002). TANGSERV: A multiple item scale for measuring tangible quality in foodservice industry. Journal of Foodservice Business Research, 5(2), 109-127.

Rust, R. T., \& Oliver, R. L. (1994). Service quality: Insights and managerial implications from the frontier, Sage, Thousand Oaks, CA.

SPSS (1998). AnswerTree 2.0 User's Guide, Retrieved from http://www.uic.edu/classes/idsc/ids422/trees.pdf

SPSS (2009). How decision tree results are different in AnswerTree. Retrieved from http://www.spss.com/answertree/decisiontrees.htm

Stevens, P., Knutson, B., \& Patton, M. (1995). DineServ: A tool for measuring service quality in restaurants. Cornell Hotel and Restaurant Administrative Quarterly, 36(3), 56-60.

Tam, J. L. M. (2000). The effects of service quality perceived value and customer satisfaction on behavioral intentions. Journal of Hospitality \& Leisure Marketing, 6(4), 31-43. 
Tse, D., \& Wilton, P. C. (1988). Models of consumer satisfaction formation: An extensive. Journal of Marketing Research, 25(2), 204-212.

Umbrell, C. (2003). Gold star service. American-Gas, 85(4), 14-16.

Vavra, T. G. (1997). Improving your measurement of customer satisfaction: A guide to creating, conducting, analyzing, and reporting customer satisfaction measurement programs, ASQ quality press.

Witkowski, T. H., Ma, Y., \& Zheng, D. (2003). Cross-cultural influences on brand identity impressions: KFC in China and the United States. Asia Pacific Journal of Marketing and Logistics, 15(1/2), 74-88.

Yüksel, A., \& Yüksel, F. (2002). Measurement of tourist satisfaction with restaurant services: A segment-based approach. Journal of Vacation Marketing, 9(1), 52-68.

Zeithaml, V. A. (1988). Consumer perceptions of price quality and value: A means-end model and synthesis of evidence. Journal of Marketing, 52(3), 2-22.

Zeithaml, V. A., \& Bitner, M. J. (2000). Services Marketing: Integrating Customer Focus Across the Firm, McGraw-Hill NY. 
Figure 1. General model of satisfied and dissatisfied groups

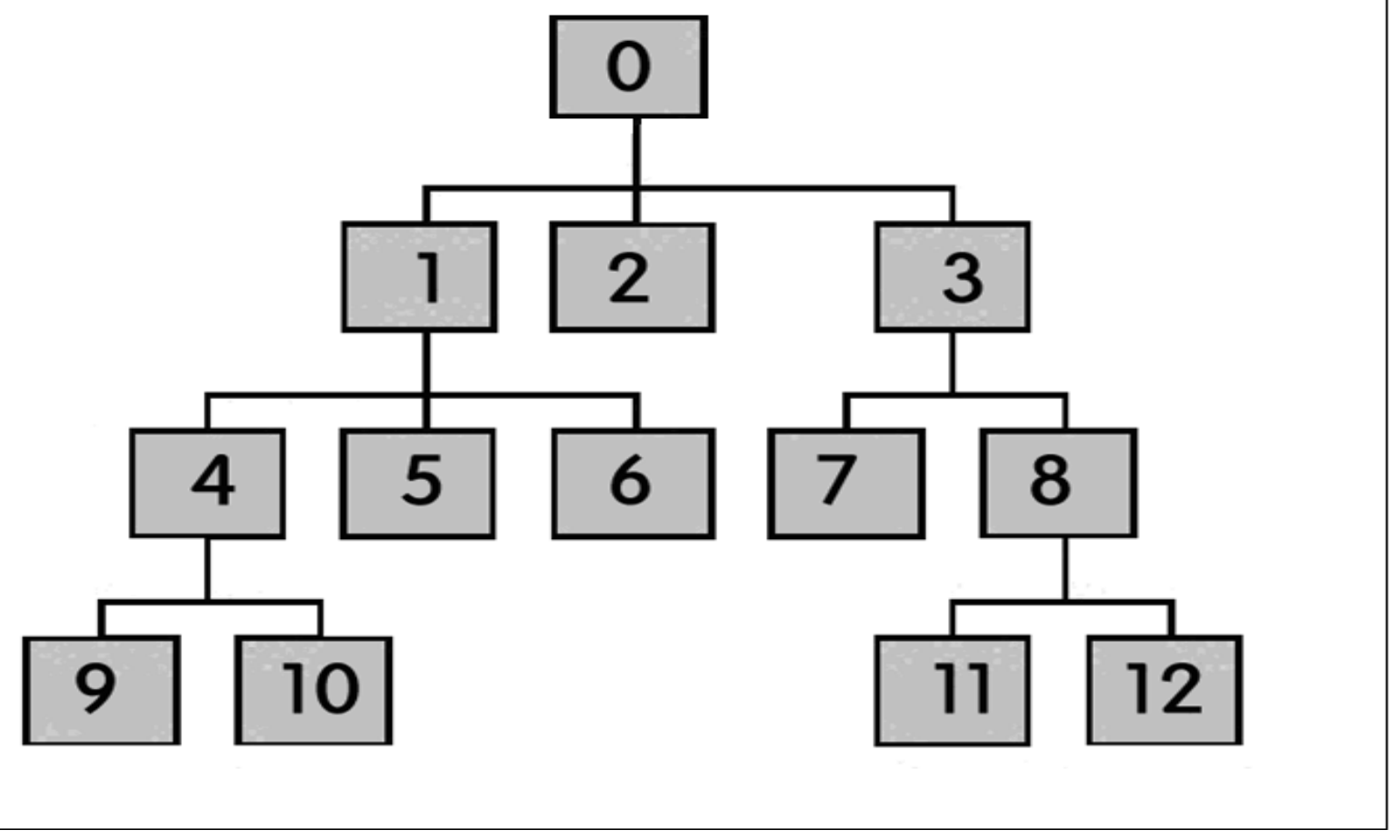


Figure 2. The result of the satisfied group

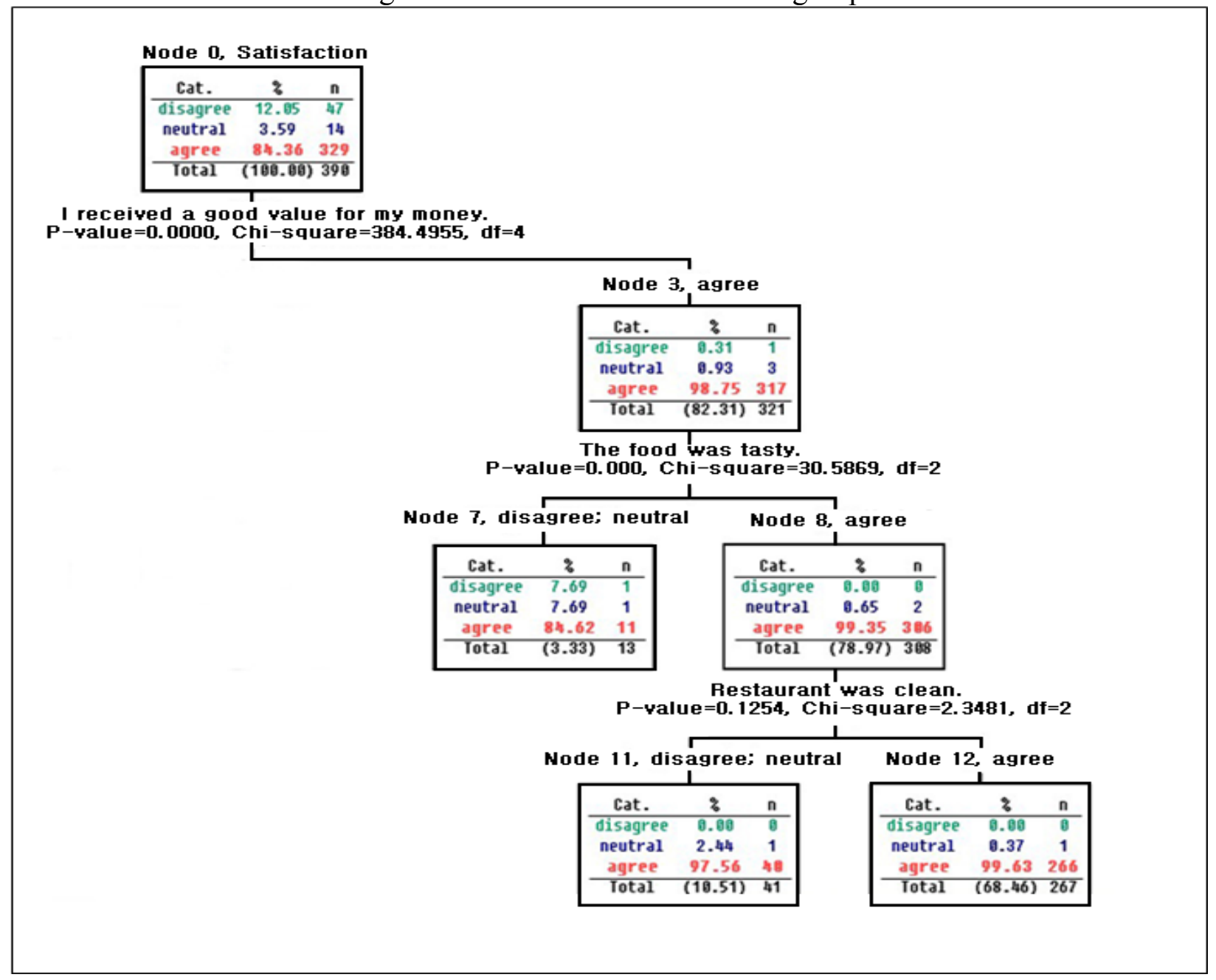


Figure 3. The result of the dissatisfied group

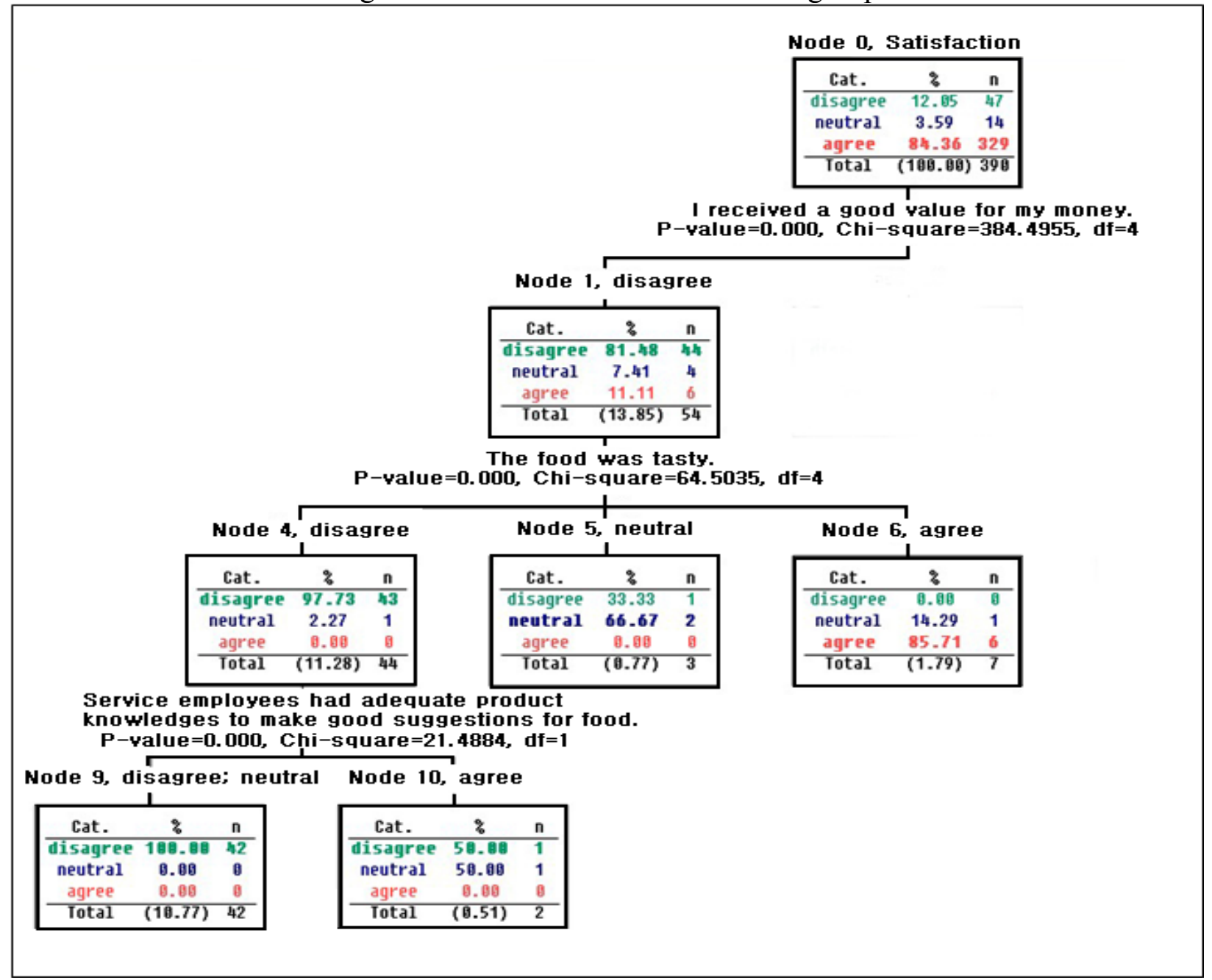


Figure 4. Bar graph of satisfied and dissatisfied groups

\section{Satisfaction}

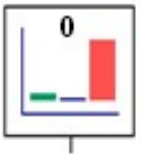

I received a good value for my money.

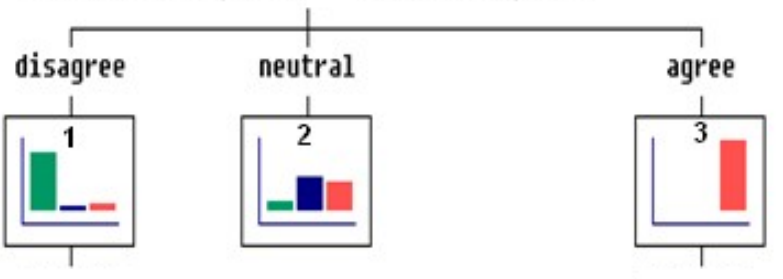

The food was tasty.

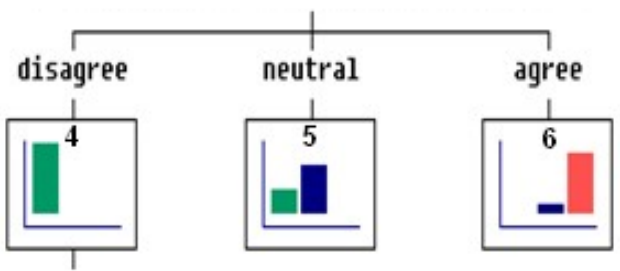

Service employees had adequate product knowleges to make good suggestions for food.

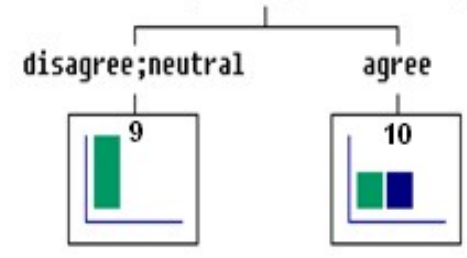

The food was tasty.

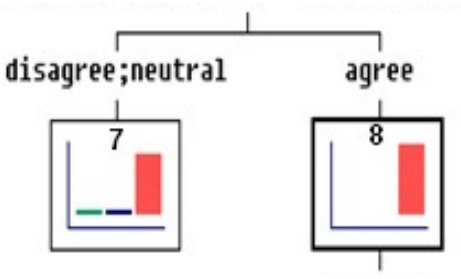

Restaurant was clean.

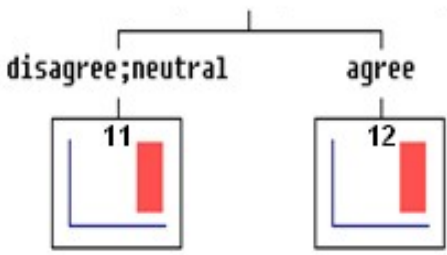




\begin{tabular}{|c|c|c|c|c|c|}
\hline \multirow{2}{*}{\multicolumn{2}{|c|}{$\begin{array}{ll} & \\
\end{array}$}} & \multicolumn{4}{|c|}{ Level of Satisfaction } \\
\hline & & Disagree & Neutral & Agree & Total \\
\hline \multicolumn{2}{|l|}{ - The food quality was excellent: Disagree } & 45 & 2 & 7 & 54 \\
\hline \multicolumn{2}{|l|}{ Neutral } & 2 & 7 & 13 & 22 \\
\hline \multicolumn{2}{|l|}{ Agree } & 0 & 5 & 309 & 314 \\
\hline \multicolumn{2}{|l|}{ - The food temperature was good: Disagree } & 22 & 4 & 5 & 31 \\
\hline \multicolumn{2}{|l|}{ Neutral } & 25 & 5 & 12 & 42 \\
\hline \multicolumn{2}{|l|}{ Agree } & 0 & 5 & 312 & 317 \\
\hline \multicolumn{2}{|l|}{ - The food was tasty: Disagree } & 45 & 2 & 4 & 51 \\
\hline \multicolumn{2}{|l|}{ Neutral } & 2 & 6 & 9 & 17 \\
\hline \multicolumn{2}{|l|}{ Agree } & 0 & 6 & 316 & 322 \\
\hline \multicolumn{2}{|l|}{ - The drink was excellent: Disagree } & 41 & 3 & 26 & 70 \\
\hline \multicolumn{2}{|l|}{ Neutral } & 5 & 7 & 184 & 196 \\
\hline \multicolumn{2}{|l|}{ Agree } & 1 & 4 & 119 & 124 \\
\hline \multicolumn{2}{|l|}{ - The service was prompt: Disagree } & 4 & 5 & 54 & 63 \\
\hline \multicolumn{2}{|l|}{ Neutral } & 21 & 5 & 155 & 181 \\
\hline \multicolumn{2}{|l|}{ Agree } & 22 & 4 & 120 & 146 \\
\hline \multicolumn{2}{|l|}{ - Sauces, utensils, napkins, etc., were: Disagree } & 6 & 1 & 47 & 54 \\
\hline \multirow{2}{*}{\multicolumn{2}{|c|}{ readily available on the table. }} & 38 & 5 & 153 & 196 \\
\hline & & 3 & 8 & 129 & 140 \\
\hline & 4 & 0 & 4 & 8 \\
\hline \multicolumn{2}{|l|}{$\begin{array}{r}\text { - The order was correct and complete: Disagree } \\
\text { Neutral }\end{array}$} & 2 & 2 & 9 & 13 \\
\hline \multicolumn{2}{|c|}{ Agree } & 41 & 12 & 316 & 369 \\
\hline \multicolumn{2}{|c|}{ - The menu had a good variety of items: Disagree } & 3 & 1 & 37 & 41 \\
\hline \multicolumn{2}{|c|}{ Neutral } & 4 & 3 & 27 & 34 \\
\hline \multicolumn{2}{|c|}{ Agree } & 40 & 10 & 265 & 315 \\
\hline \multicolumn{2}{|l|}{ - The menu was easy to read: Disagree } & 7 & 2 & 22 & 31 \\
\hline \multicolumn{2}{|l|}{ Neutral } & 22 & 0 & 76 & 98 \\
\hline Agree & & 18 & 12 & 231 & 261 \\
\hline - Employees spoke clearly: Disagree & & 6 & 2 & 46 & 54 \\
\hline Neutral & & 39 & 2 & 85 & 126 \\
\hline Agree & & 2 & 10 & 198 & 210 \\
\hline • Employees were friendly and courteous: & Disagree & 5 & 1 & 43 & 49 \\
\hline & Neutral & 40 & 1 & 58 & 99 \\
\hline & Agree & 2 & 12 & 228 & 242 \\
\hline - Service employees had adequate product & : Disagree & 6 & 2 & 46 & 54 \\
\hline knowledge to make good suggestions for & Neutral & 40 & 2 & 1 & 165 \\
\hline food. & Agree & 1 & 10 & 160 & 171 \\
\hline Total & & 47 & 14 & 329 & 390 \\
\hline
\end{tabular}


Table 1 (continued)

\begin{tabular}{|c|c|c|c|c|}
\hline \multirow[b]{2}{*}{ Variable } & \multicolumn{4}{|c|}{ Level of Satisfaction } \\
\hline & Disagree & Neutral & Agree & Total \\
\hline - The employee uniform was appropriate: Disagree & 6 & 2 & 7 & 15 \\
\hline Neutral & 3 & 2 & 154 & 159 \\
\hline Agree & 38 & 10 & 168 & 216 \\
\hline - Restaurant had a good ambience: Disagree & 7 & 0 & 31 & 38 \\
\hline Neutral & 2 & 8 & 18 & 28 \\
\hline Agree & 38 & 6 & 280 & 324 \\
\hline - Restaurant was clean: Disagree & 7 & 5 & 21 & 44 \\
\hline Neutral & 2 & 3 & 13 & 18 \\
\hline Agree & 38 & 6 & 284 & 328 \\
\hline - Restaurant had adequate parking spaces: Disagree & 5 & 3 & 16 & 24 \\
\hline Neutral & 2 & 3 & 64 & 69 \\
\hline Agree & 40 & 8 & 249 & 297 \\
\hline - Location of the restaurant was convenient: Disagree & 19 & 4 & 5 & 28 \\
\hline Neutral & 3 & 3 & 59 & 65 \\
\hline Agree & 25 & 7 & 265 & 297 \\
\hline - I received a good value for my money: Disagree & 44 & 4 & 6 & 54 \\
\hline Neutral & 2 & 7 & 6 & 15 \\
\hline Agree & 1 & 3 & 317 & 321 \\
\hline Total & 47 & 14 & 329 & 390 \\
\hline
\end{tabular}


Table 2. Demographic profiles of the respondents

\begin{tabular}{c|c|c}
\hline \hline Characteristics & Frequency & Percent (\%) \\
\hline Gender & 187 & 47.9 \\
Female & 203 & 52.1 \\
Male & & \\
Age (Years) & 144 & 36.9 \\
Below 30 & 124 & 31.8 \\
$31-40$ & 78 & 20.0 \\
$40-51$ & 44 & 11.3 \\
Over 51 & 154 & 39.5 \\
Marital status & 230 & 59.0 \\
Single & 2 & 0.5 \\
Married & 4 & 1.0 \\
Widow / Widower & & \\
Divorced & 80 & 20.5 \\
Ethnicity & 132 & 33.8 \\
Black/afro-American & 82 & 21.0 \\
White/Caucasian & 92 & 23.6 \\
Asian & 4 & 1.0 \\
Hispanic & & \\
Other & 129 & 33.1 \\
Income (\$) & 114 & 29.2 \\
Below 40000 & 26 & 6.7 \\
41000-50000 & 28 & 7.2 \\
51000-60000 & 27 & 6.9 \\
61000-70000 & 66 & 16.9 \\
71000-80000 & $\mathbf{3 9 0}$ & $\mathbf{1 0 0 . 0}$ \\
Over 81000 & & \\
Total & & \\
\hline
\end{tabular}


Table 3. Gain chart of the satisfied group

Target variable: Important Factor; Target category: Agree Node by Node

\begin{tabular}{c|c|c|c|c|c|c}
\hline Node & Node: $\mathrm{N}$ & Node: $\%$ & Resp: $\mathrm{N}$ & Resp: \% & Gain: \% & Index: \% \\
\hline 12 & 267 & 68.46 & 266 & 80.85 & 99.62 & 118.09 \\
\hline 11 & 41 & 10.51 & 40 & 12.16 & 97.56 & 115.64 \\
\hline 6 & 7 & 1.79 & 6 & 1.82 & 85.71 & 101.60 \\
\hline 7 & 13 & 3.33 & 11 & 3.34 & 84.61 & 100.30 \\
\hline
\end{tabular}


Table 4. Gain chart of the dissatisfied group Target variable: Important Factor; Target category: Disagree Node by Node

\begin{tabular}{c|c|c|c|c|c|c}
\hline Node & Node: $\mathrm{N}$ & Node: $\%$ & Resp: $\mathrm{N}$ & Resp: \% & Gain: \% & Index: \% \\
\hline 9 & 42 & 10.77 & 42 & 89.36 & 100.00 & 829.78 \\
\hline 10 & 2 & 0.51 & 1 & 2.13 & 50.00 & 414.89 \\
\hline 5 & 3 & 0.77 & 1 & 2.13 & 33.33 & 276.59 \\
\hline
\end{tabular}


Table 5. Risk chart of satisfied and dissatisfied groups

\begin{tabular}{|c|c|c|c|c|c|}
\hline \multicolumn{6}{|c|}{ Misclassification Matrix } \\
\hline & & & Ac & egory & \\
\hline & & No & Soso & Yes & Total \\
\hline \multirow{5}{*}{$\begin{array}{l}\text { Predicted } \\
\text { Category }\end{array}$} & No & 43 & 1 & 0 & 44 \\
\hline & Soso & 3 & 9 & 6 & 18 \\
\hline & Yes & 1 & 4 & 323 & 328 \\
\hline & Total & 47 & 14 & 329 & 390 \\
\hline & \multicolumn{5}{|c|}{ Resubstitution } \\
\hline Risk Estimate & \multicolumn{5}{|c|}{0.0384615} \\
\hline SE of Risk Estimate & \multicolumn{5}{|c|}{0.00973788} \\
\hline
\end{tabular}

